Ferguson, A. (2010). Critical tensions in talk about brain injury. Brain Impairment, 11 (1), 17-30.

\title{
Critical tensions in talk about brain injury
}

\author{
Alison Ferguson ${ }^{1}$ \\ University of Newcastle, Australia
}

\begin{abstract}
This paper presents an introduction to some potential applications of a critical discourse perspective to the field of traumatic brain injury. Critical Discourse Analysis (CDA) examines spoken and written texts as a means to understand the two-way relationship between discourse and cultural context. CDA is particularly interested in how language use reflects and creates power relationships between those involved in the communication. In order to illustrate this perspective, this paper discusses a purposively selected set of written texts about brain injury from a range of institutional contexts: a scholarly journal article, a submission to government from an advocacy group, the home web page of a support group, a newspaper article from the general media, and personal letters written by people with traumatic brain injury. The analysis involved investigation of key linguistic features reflecting the experiential, interpersonal and textual aspects of these texts. Three main lines of tension between competing discourses emerged from an examination. Tension emerged within each text between medical vs. lay terminology, and this was seen as reflecting the widespread power of the scientific paradigm. Tension was apparent between problem talk vs. positive talk. Talk about the problems associated with brain injury forms an essential component when seeking support, and yet talk about positive outcomes forms an essential component when describing the rehabilitation journey. There were also competing discourses in terms of the focus of the talk, between person centredness vs. other centredness. The methodology of CDA is proposed as a tool for reflective clinical practice at both an individual and professional level, as it provides a systematic means to examine health professionals' interactions and promotes the development of a critical understanding of the cultural ideologies and institutions in which practice is located.
\end{abstract}

Keywords: traumatic brain injury, critical discourse analysis, linguistic analysis, qualitative research

\footnotetext{
${ }^{1}$ Address for correspondence: Alison Ferguson, PhD, Associate Professor in Speech Pathology, School of Humanities and Social Science, University of Newcastle, Callaghan NSW Australia. E-mail: Alison.Ferguson@newcastle.edu.au
} 
This paper introduces the approach of Critical Discourse Analysis (CDA) and explores its applications to the field of Traumatic Brain Injury (TBI). Methods of discourse analysis have a long history of application to the field of TBI (for example, Togher, 2001) and have provided invaluable insights into the relationship of cognitive impairment and communication (see Bloom, Borod, Obler, \& Gerstmann, 1993; Chapman et al., 1992; Chapman, Levin, Wanek, Weyrauch, \& Kufera, 1998; Coelho, 1995; Coelho, Youse, \& Le, 2002; Hartley \& Jensen, 1991, 1992; Sherratt \& Penn, 1990; Snow, Douglas, \& Ponsford, 1998; Wilson, 2002), as well as into the consequences of brain impairment for the communicative interaction between people with TBI and their communication partners (see Galski, Tompkins, \& Johnston, 1998; Kilov, Togher, \& Grant, 2008; Togher, Hand, \& Code, 1997). While the studies that have made use of discourse analysis have noted the importance of cultural and situational context on the discourse produced and examined, this recognition has been restricted to the careful description and control (when appropriate) of aspects of context considered to be potential factors influencing the nature of the discourse (Togher, 2000), for example, the type of communication partner or the setting in which the discourse took place. However, from the discourse perspective of Systemic Functional Linguistics (SFL), the role of cultural and situational context is placed more centrally, as it is recognised that the way individuals use language both reflects and creates the cultural and situational context (Halliday \& Hasan, 1985; Halliday \& Matthiessen, 1999; Hasan, 1994). For example, the degree of formality that occurs within workplaces may reflect the type of organisation, or the purpose of the talk, but individuals are able to reframe expectations through their own contributions (Koester, 2006; Sarangi \& Roberts, 1999).

This wider perspective on the role of cultural and situational context is consistent with relatively recent developments within a range of approaches that share a common ground in applying ‘critical theory’ (for an overview, see Tyson, 2006). Critical approaches share a 
postmodern perspective in that they are concerned with identifying relative interpretations of phenomena, rather than universal or absolute truths, and so are commonly associated with qualitative research methodologies (for example, Kemmis, 2001). Critical approaches draw heavily on the philosophical works of Foucault (Foucault, 1966/1994, 1994/1983), Bourdieu (2006), and Derrida (2004) amongst others. For the purposes of this discussion, it is relevant to note Foucault's attention to 'discourse artefacts' as a form of 'archeological' evidence of the cultural power of institutions. Foucault's analysis of the historical changes in how mental health problems were conceived and managed made use of the analysis of discourse documents as reflections of the institutions through which they were created (Foucault, 1965). Foucault's identification of the central role of institutionally created and enacted power is echoed in the work of Bourdieu, who was concerned with language as a primary vehicle for symbolic power (Bourdieu, 2006). Derrida’s work coined the term 'deconstruction' to describe the process of analysing and identifying the cultural origins of socially produced discourse (for an introduction, see Reynolds \& Roffe, 2004), and the methods of linguistic analysis have been harnessed as a primary methodology in performing such deconstruction through CDA (Fairclough, 1995b). Fairclough's description of the aims of CDA captures the key features of this approach:

“...to systematically explore often opaque relationships of causality and determination between (a) discursive practices, events and texts, and (b) wider social and cultural structures, relations and processes; to investigate how such practices, events and texts arise out of and are ideologically shaped by relations of power and struggles over power (Fairclough, 1995b: 132)

While a range of methodological approaches are used within CDA (see Wodak \& Meyer, 2009), the perspective of SFL has proved to be particularly useful, as this linguistic approach explicitly and systematically articulates the probabilistic relationship between cultural and situation context and specific linguistic features (L. Young \& Harrison, 2004). 
CDA has been used in a number of fields relevant to the understanding of brain impairment and its consequences. For example, studies in second language learning have been concerned with how variation from the target language are judged (Fairclough, 1995a), and such social judgments as to 'appropriateness' raise similar issues to those arising from changes in communication and behaviour following TBI (for example, Vanhalle et al., 2000). Studies in education have been particularly concerned with literacy and its relationship to social disadvantage (Rogers, 2004), and these studies resonate with the socially-skewed distribution of TBI (Fortune \& Wen, 1999) and raise important questions about the potential for compounded disadvantage for children and adolescents with TBI. Critical approaches have been applied extensively in the area of disability (Ruiz, 1995; Skrtic, 1995; Thomas, 2007), although in this area the primary research methodology has been qualitative, with linguistic approaches centring on narrative analysis (Mattingly \& Garro, 2000; Roth \& Spekman, 1986; K. Young, 2006). Recently, the present author has made use of CDA to reflect on the social construction of the field of speech-language pathology (Ferguson, 2008b), by reviewing assessment practices for aphasia (Ferguson, 2008a), through the analysis of Scope of Practice documents of professional associations (Ferguson, 2009), and through the comparison of professional and support group web-based information about aphasia (Armstrong, Ferguson, \& Mortensen, in press).

In this paper, in order to illustrate the potential for CDA in the field of brain impairment, five written texts concerned with TBI have been selected purposively from a range of institutional contexts: a scholarly journal article, a submission to government from an advocacy group, the home web page of a support group, a newspaper article from the general media, and personal letters written by people with traumatic brain injury. The texts are described from within the framework of Systemic Functional Linguistics (Halliday \& Matthiessen, 2004) in order to describe their cultural and situational context, and then 
selected linguistic analyses are used to describe the ways in which these texts reflect and create the social power relationships within that context. Further qualitative analysis considers the competing discourses embodied in these texts. The main focus of this paper is to address the question: What is the potential for CDA to contribute to our understanding of TBI and its consequences?

\section{Method}

\section{Texts}

The texts selected for this study reflect a convenience sample, in that all were publicly available. The texts were selected on the basis of reflecting written discourse with a range of distinctive contextual aspects. These contextual aspects were considered within the Systemic Functional Linguistic framework, so that each text needed to have a distinctive 'contextual configuration' (Hasan, 1985), that is, a unique combination of the field of discourse (realising the experiential metafunction of language), the tenor of discourse (realising the interpersonal metafunction of language), and the mode of discourse (realising the textual metafunction of language). The contextual configuration of the texts is presented in Table $\mathbf{1 .}$

\section{TABLE 1 ABOUT HERE}

The set of personal letters used in this study were reported in Mortensen's research that compared the semantic and rhetorical features across a range of genres for individuals with acquired brain injury (TBI, dementia) and normal controls (Mortensen, 2003, 2005). The personal letters written by people with TBI were written in response to a research task, in which they were asked to write a letter to a friend. No particular topic was prescribed for the letter, however five of the ten participants with TBI provided an update to a friend regarding 
their injury and progress, and these five letters were selected for this study. The letter writers were five individuals (two males, three females) with TBI from motor vehicle accidents and a train accident, time post onset ranging between three to seven months, Post Traumatic Amnesia of seven, 10, and 67 days (not recorded for two individuals), all described as having mild to moderate cognitive-language deficits, and one being described as also presenting with mild aphasia. Their letters were collated and analysed as one set of data for the purposes of this study.

The newspaper article was obtained from the general media, and was a feature article that appeared in The Herald (Newcastle, Saturday November 8, 2008, pages 6-7), attributed through by-line as written by journalist, Jo Simpson. The media article comprised a description of the general features of TBI, along with a major focus on a local university student in his early 20s who had sustained a TBI from a motor vehicle accident nearly three years prior to the article being written. Included in the article were direct quotes from the individual with TBI, his mother, a number of health professionals who had been involved in his care, and members of community groups with which he had been involved both before and after the accident.

The support group web page was publicly available from the web site for Headway Illawara (http://www.headway.org.au, accessed 13 November 2008). The only selection criterion was that the support group be a non-government organisation. The first page of the web site was used for the purposes of this study, and contained information designed for the general public about TBI as well as information about the support group and its purposes and activities in relation to promoting social participation and social support which appeared designed for individuals with shared experiences of TBI.

The advocacy text was a submission to government from an advocacy group, Brain Injury Australia, in response to a call for submissions from the general public to the Senate 
Community Affairs, References Committee, 'Inquiry into the Funding and Operations of the Commonwealth State Territory Disability Agreement'. The submission by Brain Injury Australia, was dated August 2006 and titled, 'I just want a life’. This submission was available to the general public from the Brain Injury Australia web site (http://www.bia.net.au, downloaded 13 November 2008). The criteria for selection of this submission were concerns with both the nature of the consequences of TBI, and the focus on socially based interventions.

The scholarly journal article (Ylvisaker, Turkstra, \& Coelho, 2005) was chosen for its focus on main problems affecting everyday function and ways to deal with this, since this was a comparable field of discourse to the other selected texts.

\section{Data Analysis}

All texts were prepared for analysis through transcription using the conventions for the software system, Systemic Analysis of Language Transcripts (SALT; Miller, 2003). The data analysis involved three main approaches: quantitative analysis, analyses based on Systemic Functional Linguistics (SFL), and qualitative analysis of content and emergent themes.

The quantitative analysis provided general description of each text in order to provide a basis for later comparisons - see Table 2. These quantitative analyses used the automated features of SALT software - number of words, number of utterance (=sentences), words per sentence. The automated features within Microsoft Word ${ }^{\circledR}$ Readability Statistics were used to for generate percent use of passives, and Flesch-Kincaid Grade Level. The size of the texts ranged from 695 words (personal letters from people with TBI) to 5,675 words (scholarly journal article). Words per sentence results were consistent with the results of the FleschKincaid Grade Level of readability and reflected the written nature of the texts. In most texts, 
the use of the passive voice similarly reflected that the texts were written rather than spoken. However, the advocacy text (a submission to a government inquiry) was notable for its unexpectedly low use of the passive (4\%).

\section{TABLE 2 ABOUT HERE}

The analyses based on SFL were concerned with those aspects of language use associated with experiential, interpersonal and textual metafunctions of language use in the texts that reflect the field, tenor and mode of discourse, respectively. Aspects of the text realising the experiential metafunction were explored through lexical analysis, focusing on the words used in the texts to describe impairment, as well as examination of pronoun use. The software program commonly used to facilitate corpus-based research - WordSmith (Scott, 1996) - was used for the lexical analysis, and automated features of SALT software were used for the analysis of pronouns. Aspects of the text realising the interpersonal metafunction were explored through analysis of linguistic features reflecting polarity (negativity), and Modality (modal auxiliaries/operators). Automated features of SALT software were also used to facilitate these analyses. Interpersonal features of the texts were further analysed for Appraisal, that is, the ways in which evaluation is expressed (Martin, 2000; Martin \& White, 2005/2007). Martin describes the evaluative use of language to describe things as Appreciation, feelings as Affect, and people/character as Judgment. The analysis of Appraisal was conducted through using the coding capacity of NVivo (Version 8) (see Richards, 2000).

The final stage of analysis identified key competing discourses evident within and across the texts, drawing from the results of the above analyses and making use of the principles of content and thematic analysis (Liamputtong \& Ezzy, 2005). Three key 
competing discourses were identified: medical vs. lay talk, problem vs. positive talk; and person vs. other centredness in rehabilitation.

\section{Results}

In this section, the results from the specific linguistic analyses and the wider discourse analyses are organised for the purposes of presentation within the three key competing discourses identified through the analyses. Three main lines of tension emerged from an examination of this discourse: medical vs. lay talk; problem vs. positive talk, and person vs. other centredness in rehabilitation. The directions for possible interpretation of specific findings will be discussed through the presentation of results. In line with the stated aim of this paper to address the potential for CDA to contribute to our understanding of TBI and its consequences, it needs to be recognised that these findings are not proposed as generalisable, but rather as illustrative of the types of issues and questions that CDA can generate for further consideration.

\section{Medical vs. lay talk}

It was expected that the different texts would use medical and lay terminology to varying extents, reflecting their different institutional origins. The ways in which the different texts used linguistic resources to talk about the nature of TBI was examined. The texts shared a common field of discourse in that they were concerned with TBI, and so it was expected that there would be considerable similarity in the lexical choices made within each text. The automated word frequency analysis (Scott, 1996) identified words in the form in which they occurred in the text, so that, for example, the word 'rehabilitation' occurred 25 times across 
the five texts, while 'rehabilitative' occurred three times but in only one text. The analysis focused on the most commonly occurring forms of words only. There were 21 content words that occurred across at least four of the five texts, and these are listed in Table 3, along with their overall frequency of occurrence. Within this set of words, as could be expected due to their purposive selection, these texts shared a common concern with brain, injury, and rehabilitation. The places involved were prominent - home, hospital, work, as was the period of involvement - time, year/s. Another cluster of words in this set highlighted the impact of TBI- life, social, people and family/ies. The appearance of the word, control, on seven occasions in four of the five texts was of interest, given the CDA focus on power. In the scholarly text, control appeared on two occasions in relation to reported experimental design, and one occasion describing 'reduced anger control' associated with frontal lesions. This association of control with problems following TBI was also found for its occurrence in the advocacy text ('poor control over emotions'). In the media text, control appeared in relation to describing brain function ('the hand section of the brain could be 'remapped' to the undamaged control centre for the foot'). In the personal letters of the people with TBI, control was used in relation to the cause of the TBI ('an inexperienced driver, who lost control of the vehicle'). The word control did not appear in the support group text.

In these texts, control appears as valued (required for brain function, and scientific), and loss of control is both cause and consequence of brain damage. Critical theorists (McHoul \& Grace, 1993) see the role of power (i.e., the power to act) as a fundamental source of explanation for understanding the social world. From a CDA perspective, the power to act autonomously is seen to be restricted through social attribution of incompetence (Kovarsky, Duchan, \& Maxwell, 1999), and so loss of control is one of the features that threatens the autonomous action of people with TBI. Loss of control is viewed negatively, and for people with TBI there is also a social penalty in situations in which their actions are 
perceived as contributing to the cause of the TBI (i.e. with the power to act, comes responsibility for actions) (e.g., O'Callaghan, Hahn, Christison, \& Haviland, 2004).

\section{TABLE 3 ABOUT HERE}

The ways in which the changes in the person following TBI were conceptualised in the different texts were examined through comparing the frequency of use of words that related to 'disorder': damage, difficulty; disability, disorder, impairment, injury, problem, and trouble - see Table 4. The advocacy text used all eight terms, the scholarly text used seven of the terms (not trouble), and the media text used five of the terms (not disorder, problem, or trouble). The support group text used only three of the terms, making most use of injury (14/986, 1.4\%), and only using damage and disability once. The personal letters of the people with TBI made use of injury only (4/695, 0.6\%). In these letters, difficulties are able to be inferred from the description of current abilities and activities, e.g., 'Not as weak as a month ago and physio once a week. I'm swimming about five out of seven days and going for a walk'. These different kinds of talk expressed the negative consequences of TBI in different ways - that is, the scholarly, advocacy and media texts could be seen as packaging the negative changes as 'things' or 'conditions', in contrast with the support group and personal texts which expressed difficulties in terms of actions or functions that cannot be performed. This making of illness into a commodity has been suggested to be part of a wider sociocultural shift toward increasing ‘corporatisation’ (Fairclough, 2004) where health services are packaged and traded, rather than performed.

\section{TABLE 4 ABOUT HERE}


However, what did not emerge from this analysis was any clear association of medical terminology with texts produced within more medical institutional contexts. Instead, medical and lay terminology formed competing discourses within some texts. In the personal letters of the people with TBI, writers adopted medical terminology to describe what had happened to them, for example, "I suffered extensive facial and head injuries and broke every bone in my face. The left arm received the brunt of the impact and I broke two metacarpels in my hand'. This scientific talk was seen not only in the terms used, but in the adoption of the impersonal 'the left arm' and the passive voice, instead of saying, for example, 'I broke my left arm'. In the media text, there was an interesting counterpointing of the two discourses, where in the body of the article, the journalist described TBI using a medical frame of reference, for example, 'The impact of the accident caused (his) frontal lobe to slam into his skull. The base of his brain and the brain stem were severely shaken. Everything that creates personality, memories, consciousness, emotions, is stored in the frontal lobe, while the brain stem is the lifeline to bodily functions'. However, in the accompanying side-column by the same journalist headed as 'The damage done', a medical specialist was reported describing in deliberately everyday terms, the causes and complications of TBI as being associated with '...the four Bs, boys, booze, bongs and bashings'. However, the use of such lay terms was clearly marked in its usage, and was countered by the report that the medical specialist emphasised '... that brain injury was a serious matter'. Both the advocacy and the scholarly papers made use of primarily scientific medical terminology, though (as previously reported) the advocacy text avoided the use of passive voice so commonly associated with scientific writing.

Medical terminology permeated these texts, illustrating the role that scientific discourse has come to play within society in general. Scientific discourse is valued (Veel, 
1997) and the symbolic power of such discourse is harnessed by language users to enhance social credibility. From the perspective of CDA, it can be asked whether the 'voice' of the patient (Hamilton, 2003; Tannen \& Wallat, 2006) is altered or filtered through this type of language use - for example, does this adoption of scientific discourse increase the power of advocacy, or hamper its unique expression? The findings also point to political sensitivities influencing the more 'professional' texts examined, e.g., 'problem', 'trouble', whereas the support group text did not make use of such terms. Terminology is a continuing debate within the professions (Eadie, 2005; Walsh, 2005), and usually framed as from the perspective of the powerful (i.e., the need to make scientific discourse accessible to those who do not have access). The findings from this preliminary research point to more complex interactions, where the public appropriate scientific discourse to harness its power, while the professions seek to translate and appropriate 'lay' language for use in marked ways.

\section{Problem vs. positive talk}

Talk about the problems associated with brain injury forms an essential component when seeking support of the hearer/reader, and yet talk about positive outcomes forms an essential component when describing the rehabilitation journey. Each of the texts involved discussion of the negative impacts of TBI and accounts and recommendations of recovery, strategies and improvements.

The polarity of the texts was examined through the identification of negative forms, using the automated features of the SALT software - (this identifies the following negative forms: ain't, can't, couldn't, didn't, doesn't, don't, hadn't, hasn't, isn't, mightn't, mustn't, no, nope, not, shouldn't, uhuh, wasn't, weren't, won't, and wouldn't). Figure 1 presents the results of this analysis across the texts, with the number of negatives expressed as a 
percentage of the total number of sentences, in order to facilitate comparison across the texts. The personal letters showed the highest negativity (8/59, 13.6\%). The media and support texts showed equivalent negativity (12/140, 8.6\%; 5/56, 8.9\% respectively). There was lower negativity in the advocacy text $(11 / 207,5.3 \%)$ and the scholarly text $(8 / 234,3.4 \%)$.

\section{FIGURE 1 ABOUT HERE}

The stance of the speaker/writer can also be expressed through using the resources of Modality, and Appraisal. In this study, selected modal operators were examined across the texts, and these were categorised (in line with Halliday \& Matthiessen, 2004: 116), in terms of strength as low (can, may, could, might), median (will, would, should), and high (must). The results of this analysis are presented in Table 5. The proportion of use of low strength modal operators appeared similar across the texts (ranging from $6.8 \%$ in the scholarly text to $9.3 \%$ in the media text).

\section{TABLE 5 ABOUT HERE}

There appeared to be a difference in the use of median strength modal operators across the texts. The scholarly text used these less frequently (3.0\%), than the media text (6.4\%) and the support group (7.1\%). Only one instance of the high strength modal operator 'must' occurred, and this occurred in the personal letters, ('It seems that my letter arrived the same day you sent yours. We must be psychic.'). However, in this context, the strength of 'must' is lower than in its more usual use in an imperative form (e.g., You must do such-andsuch). 
The scholarly article used the resources of Modality to raise certainty, (for example, 'That evidence... should caution against reliance on currently popular intervention options...'). The media text and the support group used Modality expressing raised certainty, with frequent use of 'will' (for example, in the media text - 'some basic brain function will return', and in the support text - 'this all too often means that someone's life has or will be devastated by the after effects of a brain injury').

The linguistic resources for Appraisal are those used to express evaluation and can include singe lexical items such as adjectives ('good'), or phrases ('not as good as...'). As previously outlined, the broad categories used by Martin (Martin, 2000; Martin \& White, 2005/2007) in describing types of Appraisal were used in the present research, i.e., Appreciation - evaluation of things, Affect - evaluation of feelings, and Judgment evaluation of people or their character. The results of coding for Appraisal are presented in Figure 2 (expressed as a proportion of total sentences for each text, in order to facilitate comparison across texts). The texts with the higher proportion of evaluation were the personal letters $(15 / 59,25.4 \%)$ and the media text (34/140, 24.3\%), while the texts with the lower proportion of evaluation were the support group text $(5 / 56,8.9 \%)$ and the scholarly text (19/234, 8.1\%). The proportion of each type of Appraisal was relatively similar within the scholarly text, but for most of the other texts Appreciation was the predominant evaluation, for example, evaluating amount of difficulty or amount of change. In contrast, the media text showed proportionally more evaluation of Affect (14/140, 10\%) and Judgment (13/140, 9.3\%) than Appreciation (7/140, 5.0\%). The support group text did not use any expressions of Judgment.

FIGURE 2 ABOUT HERE 
Even within the same texts, contrasts emerged in the evaluation of the consequences of TBI. In the media text, the evaluation of the problems was emphasised using the words of the person with TBI (resources for Appraisal in bold, with type indicated in brackets) - “'I felt completely useless [Affect]', (person with TBI) said. 'I couldn't talk properly [Judgment], couldn't walk properly [Judgment]. '” In the same text, the positive evaluation associated with recovery was described, 'After he was able to walk unaided [Judgment], and with his speech restored [Judgment], he was transferred to the (rehabilitation service)'.

The same line of tension between problem vs. positive talk was seen across all the texts. For example, in the personal letters, the people with TBI provided details of severe injuries, and then added a positive note, for example, "You never really appreciate friends or indeed, your life, until you realise you almost no longer had them or it”. In the interprofessional talk, the professionals balanced the description of difficulty with a statement regarding their goal, for example, "His right upper limb is limited to 108 degrees. Hopefully botox will help". While these texts showed a balance between problem and positive talk, in contrast, problem talk outweighed positive talk in the other texts. In the advocacy text, the closest to a positive statement was, “Overcoming these barriers requires an appropriate level of support from an employment support or rehabilitation service”. And in the scholarly text, only one statement encapsulated a positive outcome from TBI, “Many people with TBI enjoy a successful social reintegration, often resulting in part from their effort and natural resilience and in part from the understanding and accommodations of everyday people in their social environments". The emphasis within these texts was overwhelmingly concerned with the problems associated with TBI.

From the observation of this line of tension in their discourse, it can be suggested that people with TBI, those representing their story for the general public, and those working directly with them in rehabilitation are heavily invested in a perspective that draws 
consolation from improvement. In contrast, the institutional context of seeking additional government support, and of seeking scientific legitimacy for approaches to intervention, sets the scene for a problem-oriented discourse. These preliminary results point toward the need for further exploration of the competing agenda that frame both personal and institutional advocacy (Munger, 2000).

\section{Person centred vs. other centred rehabilitation}

The analysis of the discourse also examined 'who' was the focus of the text - the person with TBI ('person centred'), or others? One way to gauge the extent to which the discourse was concerned with the person with TBI was to consider the use of pronouns across the texts, for example, person centredness in the personal letters would be indicated by high use of $1^{\text {st }}$ person pronouns (I/we). Figure 3 presents the proportional use of pronoun types across the five texts.

\section{FIGURE 3 ABOUT HERE}

The proportional use of pronouns reflected the purposes of the texts, so for example, the personal letters of people with TBI were chiefly about 'I' (33/62, 53.2\%) and directed to the recipient 'you' (19/62, 30.6\%). The most person centred text was the media text, in which 'he/she/they' comprised 43/64 (67.2\%) of pronouns. The advocacy text included a higher proportion of the $1^{\text {st }}$ person pronoun 'I' (20/52, 38.5\%), than might have been expected from a formal submission to a government agency, and this reflected the inclusion within the submission of a number of personal accounts of the impact of TBI from people with TBI, family members and professionals. In the support group text, the focus was on the 
role of the organisation, and so 'we' occurred in four of the 11 pronouns used, which is proportionally high, but the low number of pronouns overall needs to be noted for this text.

It was notable that the support group text was the only text characterising people with TBI as ‘clients' (one instance). This might be seen as reflecting a more institutional service relationship than might be expected from a volunteer-run organisation. The term 'patient' (in/out/patient/s) was used most frequently in the media text (nine instances), and four times in the scholarly text. These terms reflecting institutionalised relationships were absent from the other texts. The use of the term 'patient' in the media text might mirror societal expectations regarding this role, while the absence of the term in the advocacy submission was marked - possibly reflecting a conscious choice in the writing of the submission to place people with TBI within the general community.

While the notion of 'person centred' rehabilitation was only referred to explicitly in one text (the advocacy text), the concerns and priorities of people with TBI were variously portrayed. In one of the personal letters, a person with TBI stated, “I spend at least 90 percent of time doing things for someone else or things I don't like or want to. I often wonder if this is the sole reason for my temper tantrums and that they haven't actually resulted from a brain injury at all”. In the media text, the mother was reported as describing how the young man with TBI had taken up an offer to play his guitar at his church social group, but that this needed to be stopped, since “...He didn't understand that he couldn't do what he always did'. The advocacy text used the term 'person centred', and this occurred in their recommendations for the future, 'More person centred, emotional support from staff rather than a clinical approach'. The contrast drawn in this example between 'person centred' and a 'clinical approach' may add to an understanding of the medical vs. lay tension underlying these discourses (as discussed above). These data suggest a 'good' (person centred) vs 'bad' (clinical approach) dichotomy, which contrasts with the 'good' (science based) vs 'bad' 
(personal perceptions), i.e., 'good' approaches are interpersonally caring and scientific, while 'bad' approaches are interpersonally detached and subjective. Clearly, the data here is insufficient to explore this more fully, but the finding does illustrate the potential for CDA to highlight internal inconsistencies and false dichotomies (e.g., are there are other more potent influences?). A similar dichotomy was seen in the scholarly text which contrasted two main approaches to rehabilitation for TBI, described as 'applied behaviour analysis' and 'positive behaviour supports'. Applied behaviour analysis was described in this text as dependent on clinician driven analysis of behaviour and the use of observational measures to evaluate outcome. The approach of positive behaviour supports was described as resting on the assumption that contextual or environmental changes facilitate positive adjustments and appropriate behaviours, and so this approach also relies heavily on external observer description and identification of what and when to change. As could be expected, the scholarly paper dealt directly with the cognitive impairments that reduce the person's awareness or ability to self-direct or change behaviour. However, the approaches to intervention discussed in the paper, and the paper itself, did not question or critically evaluate the extent to which the cognitive impairments may or may not be seen to restrict a person centred orientation to rehabilitation, and the complex clinical and ethical decision-making around these matters (Brady Wagner, 2003).

\section{Discussion}

As discussed within the presentation of results, the findings from this research are drawn out in order to highlight how a CDA approach could offer additional understandings in the area of TBI. The limited number of texts examined preclude generalisation, and any wider conclusions depend on the extent to which the purposive selection of these texts was sufficient to be considered to be representative of typical talk about TBI. The following 
discussion is concerned with the main focus of the present paper regarding the potential for CDA to contribute to the understanding of TBI and its consequences.

The methods of analysis presented in this paper have been used in previous research in TBI within approaches informed by discourse analysis (Togher, 2001). However, in the research from a discourse analysis perspective, the role of socio-cultural context is viewed as an influencing factor on the ability of the person with TBI to exchange meaning. While such research has suggested the importance of recognising that the same communicative behaviour could be more or less competent under different circumstances, this insight is the first step in CDA (Gee, 2004). CDA sees individual communicative behaviour as an artefact of the socio-cultural context, and so when individuals produce atypical communication, this is interpreted within the frame of the socio-cultural context. For clinicians and researchers working with TBI, this shapes a profound shift toward recognising the social world within which people with TBI are living. Of course, this focus on 'the other' in rehabilitation is not unique, but a critical approach includes consideration of the therapist as not only part of the solution, but also as a potential contributor to the problem. For example, CDA prompts important questions about the socio-cultural role of the therapist in creating disability, the inherent conflict of interest for therapists where disability needs to exist to justify their social role, and the questions about political advocacy for social change (e.g., see Meagher, 2002).

Given the influence of postmodernism on CDA, it is not surprising that CDA is open to similar criticisms as those which can be raised in relation to postmodernism (Roberts, 2001). An approach that takes relativism as its essential stance predetermines its inability to find truths, or stable interpretations. Certainly, for people facing the raw experience of TBI, and for clinicians working in the here-and-now to assist, the critical reflections offered through CDA can be viewed as an abstraction. However, the concrete day-to-day situated problem solving required of people whose lives are affected by TBI fundamentally depends 
on an ability to negotiate complex and diverse value systems, in a situation where the takenfor-granted ground rules have been shifted forever by brain damage. The stance and methods used by CDA offer an alternative pathway to manage such problem-solving. CDA is designed to provoke questions, rather than address them. CDA represents one first step in a change process, in assuming that awareness is the first step toward understanding, and that understanding provides pathways for change. Thus, CDA raises questions about the inevitability of the way things are. When seen as a first step, CDA can be seen as a powerful tool to create new possibilities. In practical terms for clinical researchers, CDA becomes a potentially useful adjunct to both discourse analysis and for Participatory Action research (Balcazar et al., 2004; Kemmis \& McTaggart, 2005), as the philosophical frameworks and methodologies are at least harmonious (if not in total agreement).

This introduction to the application of CDA to TBI has sought to illustrate that the tools of discourse analysis have the potential to be used to reflect on the nature and consequences of TBI as experienced by people with TBI and those who seek to work to improve the quality of life following TBI. It is suggested that CDA offers the individual clinician a data-based approach to reflective practice (Redmond, 2004; Schon, 1983), in providing a means to consider one's own talk about TBI with fellow professionals, with family members, and with people with TBI. Using CDA to guide such reflective practice enables the clinician to reflect on how his or her talk mirrors the situational and cultural context, and thereby provides a pathway for changing talk, and in doing so, changing practice. CDA also offers a pathway for change at an institutional level, for example, in a profession or service setting or governmental agency, through holding up a mirror to reflect on how the talk of the institution relates to hidden agenda, conflict of interest, or the best interests of people with TBI. 


\section{References}

Armstrong, E., Ferguson, A., \& Mortensen, L. (in press). Public and private identity: The coconstruction of aphasia through discourse. In C. N. Candlin \& J. Crichton (Eds.), Discourses of deficit. Basingstoke: Palgrave Macmillan.

Balcazar, F. E., Taylor, R. R., Kielhofner, G. W., Tamley, K., Benziger, T., Carlin, N., et al. (2004). Participatory action research: General principles and a study with a chronic health condition. In L. A. Jason (Ed.), Participatory community research: Theories and methods in action. Washington, DC: American Psychological Association (PsycBOOKS Online Service, Retrieved 27 July 2006).

Bloom, R. L., Borod, J. C., Obler, L. K., \& Gerstmann, L. J. (1993). Suppression and facilitation of pragmatic performance: Effects of emotional content on discourse following right and left brain damage. Journal of Speech and Hearing Research, 36, 1227-1235.

Bourdieu, P. (2006). Language and symbolic power (ch.32). In A. Jaworski \& N. Coupland (Eds.), The discourse reader (2nd ed., pp. 480-490). London: Routledge [first published 1991 in Language and symbolic power, edited by John B. Thompson, translated by Gino Raymond and Matthew Adamson, Polity Press in association with Blackwell].

Brady Wagner, L. C. (2003). Clinical ethics in the context of language and cognitive impairment: Rights and protections. Seminars in Speech \& Language, 24(4), 275-284.

Chapman, S. B., Culhane, K. A., Levin, H. S., Harward, H., Mendelsohn, D., Ewing-Cobbs, L., et al. (1992). Narrative discourse after closed head injury in children and adolescents. Brain and Language, 43(1), 42-65.

Chapman, S. B., Levin, H. S., Wanek, A., Weyrauch, J., \& Kufera, J. A. (1998). Discourse after closed head injury in young children. Brain and Language, 61, 420-449.

Coelho, C. (1995). Discourse production deficits following traumatic brain injury: A critical review of the recent literature. Aphasiology, 9, 409-429.

Coelho, C., Youse, K. M., \& Le, K. N. (2002). Conversational discourse in closed-headinjured and non-brain-injured adults. Aphasiology, 16(4/5/6), 659-672.

Derrida, J. (2004). Positions (Originally published in France in 1972 as Positions by Les Editions de Minuit) (A. Bass, Trans.). London: Continuum.

Eadie, P. (2005). The case for public speech pathology terminology: Recognizing Dianthus caryophyllus? Advances in Speech-Language Pathology, 7(2), 91-93.

Fairclough, N. (1995a). The appropriacy of 'appropriateness'. In Critical discourse analysis: The critical study of language (pp. 233-252). London: Longman.

Fairclough, N. (1995b). Critical discourse analysis: The critical study of language. London: Longman.

Fairclough, N. (2004). Critical discourse analysis in researching language in the new capitalism: Overdetermination, transdisciplinarity, and textual analysis. In L. Young \& C. Harrison (Eds.), Systemic functional linguistics and critical discourse analysis (pp. 103-122). London: Continuum.

Ferguson, A. (2008a). A critical discourse perspective on understandings of aphasia. Paper presented at the Critical Approaches to Discourse Analysis across Disciplines (CADAAD) 2008, University of Hertfordshire, July 10-12.

Ferguson, A. (2008b). Expert practice: A critical discourse. San Diego, CA: Plural Publishing. 
Ferguson, A. (2009). The discourse of speech-language pathology. International Journal of Speech-Language Pathology, 11(2), 104-112.

Fortune, N., \& Wen, X. (1999). The definition, incidence and prevalence of acquired brain injury in Australia. Canberra: Australian Institute of Health and Welfare.

Foucault, M. (1965). Madness and civilization: A history of insanity in the Age of Reason (R. Howard, Trans.). London: Tavistock.

Foucault, M. (1966/1994). The order of things. In J. D. Faubion (Ed.), Aesthetics, method, and epistemology: Essential works of Foucault 1954-1984 (Vol. 2, pp. 261-267). London: Penguin (Originally appeared in Les Lettre francaises 1125, 31 March - 6 April 1966, pp.3-4).

Foucault, M. (1994/1983). Structuralism and post-structuralism. In J. D. Faubion (Ed.), Aesthetics, method, and epistemology: Essential works of Foucault 1954-1984 (pp. 433-458). London: Penguin (Originally appeared in Telos 16:55, 1983, pp.195-211).

Galski, T., Tompkins, C., \& Johnston, M. (1998). Competence in discourse as a measure of social integration and quality of life in persons with traumatic brain injury. Brain Injury, 12, 769-782.

Gee, J. P. (2004). Discourse analysis: What makes it critical? (Ch.2). In R. Rogers (Ed.), An introduction to critical discourse analysis in education (pp. 19-50). Mahwah, NJ: Lawrence Erlbaum.

Halliday, M. A. K., \& Hasan, R. (Eds.). (1985). Language, context, and text: Aspects of language in a social-semiotic perspective. Geelong, VIC: Deakin University.

Halliday, M. A. K., \& Matthiessen, C. (2004). An introduction to functional grammar (3rd ed.). New York: Arnold.

Halliday, M. A. K., \& Matthiessen, C. M. I. M. (1999). Construing experience through meaning: A language-based approach to cognition. London: Cassell.

Hamilton, H. E. (2003). Patient's voices in the medical world: An exploration of accounts of noncompliance. In D. Tannen \& J. E. Alatis (Eds.), Georgetown University round table on languages and linguistics 2001: Linguistics, language, and the real world Discourse and beyond (pp. 147-165). Washington, DC: Georgetown University Press.

Hartley, L. L., \& Jensen, P. J. (1991). Narrative and procedural discourse after closed head injury. Brain Injury, 54(3), 267-285.

Hartley, L. L., \& Jensen, P. J. (1992). Three discourse profiles of closed-head-injury speakers: Theoretical and clinical implications. Brain Injury, 6(3), 271-282.

Hasan, R. (1985). The structure of a text. In M. A. K. Halliday \& R. Hasan (Eds.), Language, context, and text: Aspects of language in a social-semiotic perspective (pp. 184-211). Geelong, VIC: Deakin University Press.

Hasan, R. (1994). Situation and the definition of genres. In A. D. Grimshaw (Ed.), What's going on here? Complementary studies of professional talk (Vol. 2 of the Multiple Analysis Project). Norwood, NJ: Ablex.

Kemmis, S. (2001). Exploring the relevance of critical theory for action research: Emancipatory action research in the footsteps of Jurgen Habermas (ch.8). In P. Reason \& H. Bradbury (Eds.), Handbook of action research: Participative inquiry and practice (pp. 91-102). London: Sage.

Kemmis, S., \& McTaggart, R. (2005). Participatory action research. In N. K. Denzin \& Y. S. Lincoln (Eds.), The Sage handbook of qualitative research (ch.23, pp.559-603) (3rd ed.). London: Sage Publications.

Kilov, A., Togher, L., \& Grant, S. (2008). Problem solving with friends: Discourse participation and performance of individuals with and without traumatic brain injury. Aphasiology, 23(5), 584-605.

Koester, A. (2006). Investigating workplace discourse. London: Routledge. 
Kovarsky, D., Duchan, J. F., \& Maxwell, M. (Eds.). (1999). Constructing (In)competence: Disabling evaluations in clinical and social interaction. Mahwah, NJ: Lawrence Erlbaum.

Liamputtong, P., \& Ezzy, D. (2005). Making sense of qualitative data (ch.12). In Qualitative research methods (2nd ed., pp. 257-285). Oxford: Oxford University Press.

Martin, J. R. (2000). Beyond exchange: Appraisal systems in English. In S. Hunston \& G. Thompson (Eds.), Evaluation in text (pp. 143-175). Oxford: Oxford University Press.

Martin, J. R., \& White, P. R. R. (2005/2007). The language of evaluation: Appraisal in English. Houndsmills, Basingstoke, Hampshire: Palgrave Macmillan.

Mattingly, C., \& Garro, L. C. (Eds.). (2000). Narrative and the cultural construction of illness and healing. Berkeley: University of California Press.

McHoul, A., \& Grace, W. (1993). A Foucault primer: Discourse, power and the subject. Melbourne: Melbourne University Press.

Meagher, J. (2002). Partnership or pretence: A handbook of empowerment and self advocacy for consumers of psychiatric services and those who provide or plan those services: A personal contribution to the development of the psychiatric consumer movement in Australia (3rd ed.). Strawberry Hills, NSW: Psychiatric Rehabilitation Association.

Miller, J. F. (2003). Systematic Analysis of Language Transcripts - SALT (Version V8.0). Madison, WI: Language Analysis Laboratory, University of Wisconsin-Madison.

Mortensen, L. (2003). Reconstructing the writer: Acquired brain impairment and letters of community membership. Unpublished Unpublished $\mathrm{PhD}$ thesis, Macquarie University, Sydney.

Mortensen, L. (2005). Written discourse and acquired brain impairment: Evaluation of structural and semantic features of personal letters from a Systemic Functional Linguistic perspective. Clinical Linguistics \& Phonetics, 19(3), 227-247.

Munger, M. C. (2000). Experts and 'Advocacy': The limits of policy analysis (ch.5). In Analyzing policy: Choices, conflicts, and practices (pp. 134-161). New York: W.W. Norton.

O'Callaghan, T. A., Hahn, J., Christison, G., \& Haviland, M. (2004). Medical students attitudes toward trauma patient encounters. Critical Care Medicine, 32(12 Suppl), A2.

Redmond, B. (2004). Reflection in action: Developing reflective practice in health and social services. Burlington, VT: Ashgate.

Reynolds, J., \& Roffe, J. (2004). Understanding Derrida. New York: Continuum.

Richards, L. (2000). Using NVivo in qualitative research. Bundoora, VIC: QSR.

Roberts, C. (2001). 'Critical' social theory: Good to think with or something more? (ch.12). In N. Coupland, S. Sarangi \& C. N. Candlin (Eds.), Sociolinguistics and social theory (pp. 323-333). Harlow, England: Longman.

Rogers, R. (Ed.). (2004). An introduction to critical discourse analysis in education. Mahwah, NJ: Lawrence Erlbaum.

Roth, F., \& Spekman, N. (1986). Narrative discourse: Spontaneously generated stories of learning-disabled and normally achieving students. Journal of Speech \& Hearing Disorders, 51, 8-23.

Ruiz, N. T. (1995). The social construction of ability and disability: II. Optimal and at-risk lessons in a bilingual special education classroom. Journal of Learning Disabilities, 28(8), 491-502.

Sarangi, S., \& Roberts, C. (Eds.). (1999). Talk, work and institutional order. Berlin: Mouton de Gruyter.

Schon, D. A. (1983). The reflective practitioner: How professionals think in action. New York: Basic Books.

Scott, M. (1996). Wordsmith tools. Oxford: Oxford University Press. 
Sherratt, S., \& Penn, C. (1990). Discourse in a right-hemisphere brain-damaged subject. Aphasiology, 4, 539-560.

Skrtic, T. M. (1995). Power/knowledge and pragmatism: A postmodern view of the professions (ch.2). In T. M. Skrtic (Ed.), Disability and democracy: Reconstructing (special) education for postmodernity (pp. 25-62). New York, NY: Teachers College Press, Columbia University.

Snow, P., Douglas, J., \& Ponsford, J. (1998). Conversational discourse abilities following severe traumatic brain injury: A longitudinal follow-up. Brain Injury, 11, 911-935.

Tannen, D., \& Wallat, C. (2006). Interactive frames and knowledge schemas in interaction: Examples from a medical examination/interview (ch.24). In A. Jaworski \& N. Coupland (Eds.), The discourse reader (2nd ed., pp. 332-348). London: Routledge [first published 1987 in Social Psychology Quarterly, 50 (2), 205-216].

Thomas, C. (2007). Sociologies of disability and illness: Contested ideas in disability studies and medical sociology. New York: Palgrave Macmillan.

Togher, L. (2000). Giving information: The importance of context on communicative opportunity for people with traumatic brain injury. Aphasiology, 14, 365-390.

Togher, L. (2001). Discourse sampling in the 21st century. Journal of Communication Disorders, 34, 131-150.

Togher, L., Hand, L., \& Code, C. (1997). Analysing discourse in the traumatic brain injury population: Telephone interactions with different communication partners. Brain Injury, 11, 169-189.

Tyson, L. (2006). Critical theory today: A user-friendly guide. New York: Routledge.

Vanhalle, C., Lemieux, S., Joubert, S., Goulet, P., Ska, B., \& Joanette, Y. (2000). Processing of speech acts by right hemisphere brain-damaged patients: An ecological approach. Aphasiology, 14(11), 1127-1142.

Veel, R. (1997). Learning how to mean - scientifically speaking: Apprenticeship into scientific discourse in the secondary school (ch.6). In F. Christie \& J. R. Martin (Eds.), Genre and institutions: Social processes in the workplace and school (pp. 161195). London: Cassell.

Walsh, R. (2005). Meaning and purpose: A conceptual model for speech pathology terminology. Advances in Speech-Language Pathology, 7(2), 65-76.

Wilson, B. M. (2002). Written discourse of adolescents with closed head injury. Brain Injury, 16(11), 1011-1024.

Wodak, R., \& Meyer, M. (Eds.). (2009). Methods of critical discourse analysis. London: Sage.

Ylvisaker, M., Turkstra, L. S., \& Coelho, C. (2005). Behavioral and social interventions for individuals with traumatic brain injury: a summary of the research with clinical implications. Seminars in Speech \& Language, 26(4), 256-267.

Young, K. (2006). Narrative embodiments: Enclaves of the self in the realm of medicine (ch.28). In A. Jaworski \& N. Coupland (Eds.), The discourse reader (2nd ed., pp. 407-418). London: Routledge [first published 1989 in John Schotter and Kenneth J. Gergen (Eds) Texts of identity, London: Sage, pp.152-165].

Young, L., \& Harrison, C. (Eds.). (2004). Systemic functional linguistics and critical discourse analysis. London: Continuum. 
Table 1. Contextual configuration of selected texts

\begin{tabular}{|c|c|c|c|}
\hline Text & $\begin{array}{c}\text { Field } \\
\text { (what message is about) }\end{array}$ & $\begin{array}{c}\text { Tenor } \\
\text { (role relationship } \\
\text { between reader/writer) }\end{array}$ & $\begin{array}{c}\text { Mode } \\
\text { (role of language in the } \\
\text { message exchange) }\end{array}$ \\
\hline People with TBI & $\begin{array}{l}\text { Personal information } \\
\text { including TBI }\end{array}$ & Friends & $\begin{array}{l}\text { Written (personal } \\
\text { letter, 'written as if } \\
\text { spoken') }\end{array}$ \\
\hline Media & $\begin{array}{l}\text { Feature article about } \\
\text { recovery from TBI }\end{array}$ & 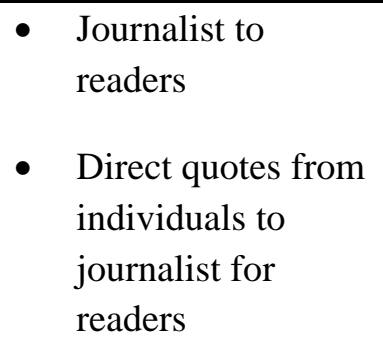 & $\begin{array}{ll}- & \begin{array}{l}\text { Written newspaper } \\
\text { (daily tabloid) }\end{array} \\
\text { - } & \text { Direct quotation of } \\
\text { spoken } \\
\text { contributions by } \\
\text { interviewees }\end{array}$ \\
\hline Support group & $\begin{array}{l}\text { Information about TBI and } \\
\text { about a support group for } \\
\text { family and individuals with } \\
\text { TBI }\end{array}$ & $\begin{array}{l}\text { Organisation } \\
\text { representative to } \\
\text { individuals from } \\
\text { general public who are } \\
\text { assumed to share } \\
\text { common concerns }\end{array}$ & Written web page \\
\hline Advocacy group & $\begin{array}{l}\text { Information about TBI and } \\
\text { needs for support from } \\
\text { government }\end{array}$ & $\begin{array}{l}\text { Organisation } \\
\text { representative to } \\
\text { government agency } \\
\text { (lobbying) }\end{array}$ & $\begin{array}{l}\text { - Written document } \\
\text { as a submission to } \\
\text { government } \\
\text { - Direct quotation of } \\
\text { spoken } \\
\text { contributions by } \\
\text { people affected by } \\
\text { TBI (individuals, } \\
\text { family, } \\
\text { professionals) }\end{array}$ \\
\hline Scholarly paper & $\begin{array}{l}\text { Information about } \\
\text { interventions for TBI }\end{array}$ & $\begin{array}{l}\text { Experts in field writing } \\
\text { for clinicians }\end{array}$ & Written journal article \\
\hline
\end{tabular}


Table 2. Indices of linguistic complexity: Quantitative description of texts

\begin{tabular}{lccccc}
\hline \multicolumn{1}{c}{ Text } & $\begin{array}{c}\# \\
\text { Words }\end{array}$ & $\begin{array}{c}\# \\
\text { Sentences }\end{array}$ & $\begin{array}{c}\text { Words } \\
\text { per } \\
\text { Sentence }\end{array}$ & $\begin{array}{c}\text { \% Passive } \\
\text { Sentences }\end{array}$ & $\begin{array}{c}\text { Flesch- } \\
\text { Kincaid } \\
\text { Grade } \\
\text { Level }^{1}\end{array}$ \\
\hline People with TBI & 695 & 59 & 12 & $0 \%$ & 6.0 \\
Media & 2443 & 140 & 18 & $10 \%$ & 9.2 \\
Support group & 986 & 56 & 18 & $17 \%$ & 11.2 \\
Advocacy group & 4282 & 207 & 21 & $4 \%$ & 13.3 \\
Scholarly paper & 5675 & 234 & 24 & $16 \%$ & 17.3 \\
\hline
\end{tabular}

${ }^{1}$ As calculated through Microsoft Word ${ }^{\circledR}$ Readability Statistics 
Table 3. Describing TBI: Frequency of content words occurring across texts

\begin{tabular}{|c|c|c|}
\hline Word Forms & $\begin{array}{c}\text { Overall } \\
\text { frequency } \\
\text { of } \\
\text { occurrence }\end{array}$ & $\begin{array}{c}\text { \# texts in } \\
\text { which these } \\
\text { word forms } \\
\text { occurred }\end{array}$ \\
\hline BRAIN & 146 & \multirow{6}{*}{$5 / 5$} \\
\hline INJURY & 139 & \\
\hline REHABILITATION & 25 & \\
\hline LIFE & 24 & \\
\hline HOME & 12 & \\
\hline HOSPITAL/S & 9 & \\
\hline SOCIAL & 94 & \multirow{15}{*}{$4 / 5$} \\
\hline PEOPLE & 78 & \\
\hline HEAD & 25 & \\
\hline FAMILY/IES & 24 & \\
\hline PERCENT & 24 & \\
\hline TIME & 24 & \\
\hline NEED & 21 & \\
\hline WORK & 20 & \\
\hline PROGRAM & 19 & \\
\hline YEARS & 17 & \\
\hline WANT/ED & 15 & \\
\hline HELP & 8 & \\
\hline BETTER & 7 & \\
\hline CONTROL & 7 & \\
\hline PLACE & 6 & \\
\hline
\end{tabular}


Table 4 . Words relating to 'disorder' (word frequency expressed as a percentage of total words for ease of comparison)

\begin{tabular}{|c|c|c|c|c|c|c|c|c|}
\hline $\begin{array}{c}\text { Text } \\
\text { (words) }\end{array}$ & Damage & Difficulty & Disability & Disorder & Impairment & Injury & Problem & Trouble \\
\hline $\begin{array}{l}\text { People } \\
\text { with TBI } \\
\text { (695) }\end{array}$ & 0 & 0 & 0 & 0 & 0 & $\begin{array}{c}4 \\
0.6 \%\end{array}$ & 0 & 0 \\
\hline $\begin{array}{l}\text { Media } \\
(2443)\end{array}$ & $\begin{array}{c}13 \\
0.5 \% \\
\end{array}$ & $\begin{array}{c}1 \\
0.04 \% \\
\end{array}$ & $\begin{array}{c}2 \\
0.08 \%\end{array}$ & 0 & $\begin{array}{c}3 \\
0.12 \%\end{array}$ & $\begin{array}{c}19 \\
0.8 \%\end{array}$ & 0 & 1 \\
\hline $\begin{array}{l}\text { Support } \\
\text { group } \\
\text { (986) }\end{array}$ & $\begin{array}{c}1 \\
0.1 \%\end{array}$ & 0 & $\begin{array}{c}1 \\
0.1 \%\end{array}$ & 0 & 0 & $\begin{array}{c}14 \\
1.4 \%\end{array}$ & 0 & 0 \\
\hline $\begin{array}{l}\text { Advocacy } \\
\text { group } \\
\text { (4282) }\end{array}$ & $\begin{array}{c}1 \\
0.02 \%\end{array}$ & $\begin{array}{c}14 \\
0.3 \%\end{array}$ & $\begin{array}{c}36 \\
0.8 \%\end{array}$ & $\begin{array}{c}1 \\
0.02 \%\end{array}$ & $\begin{array}{c}5 \\
0.2 \%\end{array}$ & $\begin{array}{c}45 \\
1.1 \%\end{array}$ & $\begin{array}{c}9 \\
0.2 \%\end{array}$ & $\begin{array}{c}1 \\
0.02 \%\end{array}$ \\
\hline $\begin{array}{l}\text { Scholarly } \\
\text { paper } \\
(5675)\end{array}$ & $\begin{array}{c}5 \\
0.1 \%\end{array}$ & $\begin{array}{c}12 \\
0.2 \%\end{array}$ & $\begin{array}{c}14 \\
0.3 \%\end{array}$ & $\begin{array}{c}3 \\
0.05 \%\end{array}$ & $\begin{array}{c}19 \\
0.3 \%\end{array}$ & $\begin{array}{c}63 \\
1.1 \%\end{array}$ & $\begin{array}{c}15 \\
0.3 \%\end{array}$ & 0 \\
\hline
\end{tabular}


Table 5. Modality (use of selected modal operators) across texts. (Modal operators expressed as a percentage of total sentences for ease of comparison.)

\begin{tabular}{lcccc}
\hline $\begin{array}{c}\text { Text } \\
\text { (\# sentences) }\end{array}$ & $\begin{array}{c}\text { Low } \\
\text { (can, may, } \\
\text { could, might) } \\
\%\end{array}$ & $\begin{array}{c}\text { Median } \\
\text { (will, } \\
\text { would, } \\
\text { should) } \\
\%\end{array}$ & $\begin{array}{c}\text { High } \\
\text { (must) }\end{array}$ & $\begin{array}{c}\text { Total } \\
\text { Modal } \\
\text { Operators } \\
\%\end{array}$ \\
\hline People with TBI (59) & 8.5 & 5.1 & 1.7 & 15.3 \\
Media (140) & 9.3 & 6.4 & 0 & 15.7 \\
Support group (56) & 7.1 & 7.1 & 0 & 14.3 \\
Advocacy group (207) & 9.2 & 4.3 & 0 & 13.5 \\
Scholarly paper (234) & 6.8 & 3.0 & 0 & 10.3 \\
\hline
\end{tabular}


Figure 1. Polarity: negatives (as a percentage of total sentences)

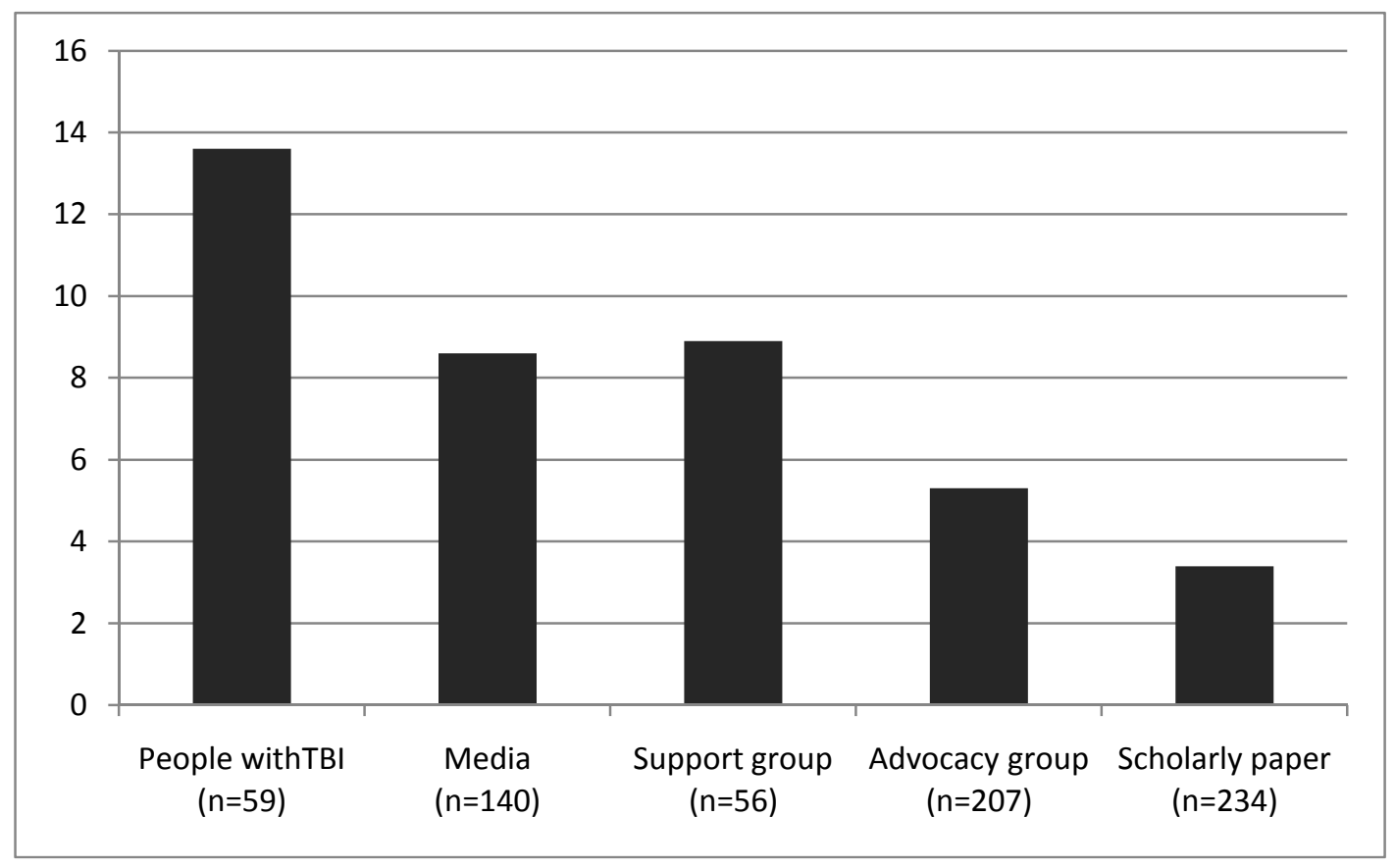


Figure 2. Appraisal across texts (coding for Appreciation, Affect, and Judgment expressed as a percent of total sentences for each text, for ease of comparison)

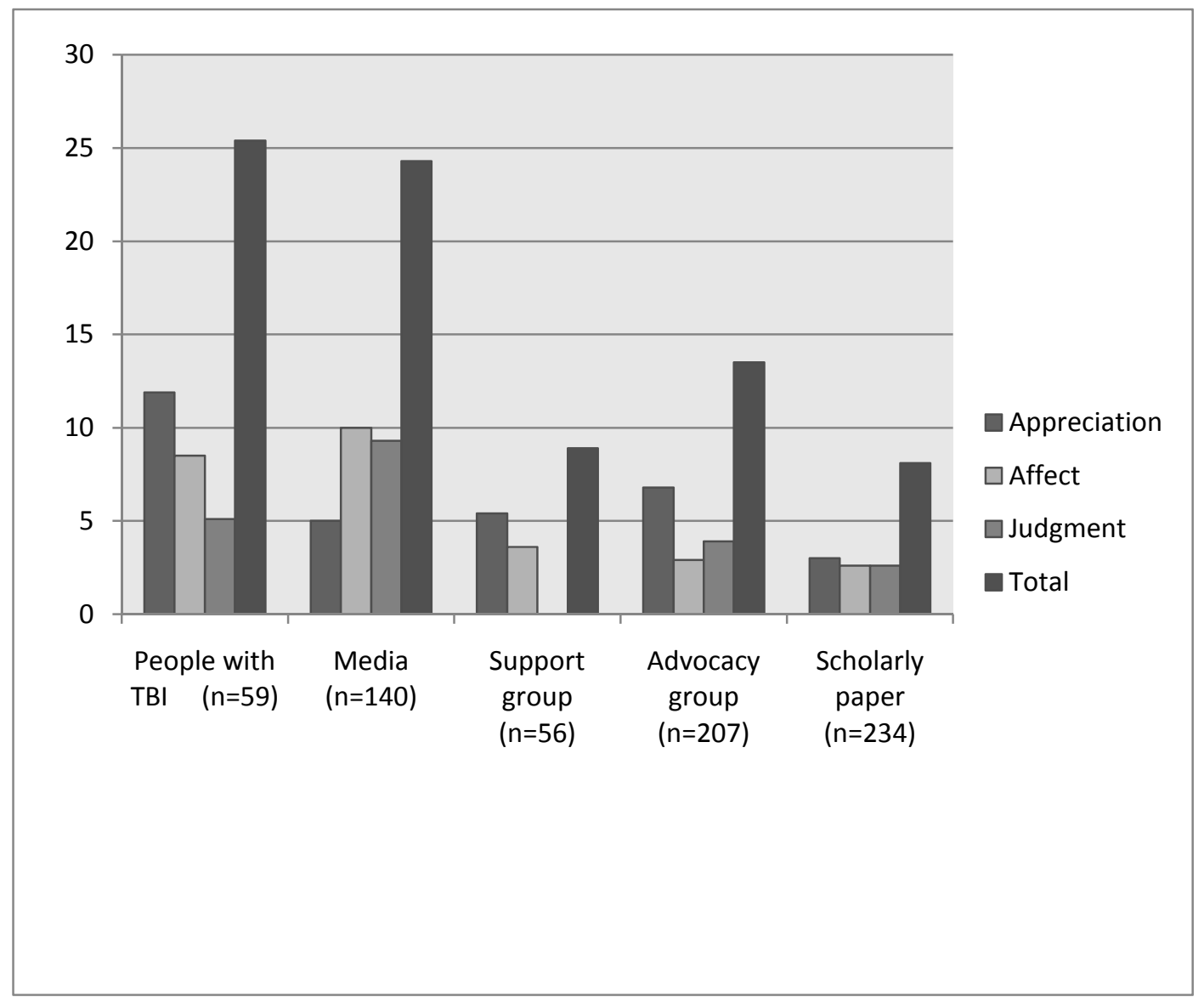


Figure 3: Person centredness - comparison across texts of use of pronouns (in nominative case) as a proportion of total pronouns

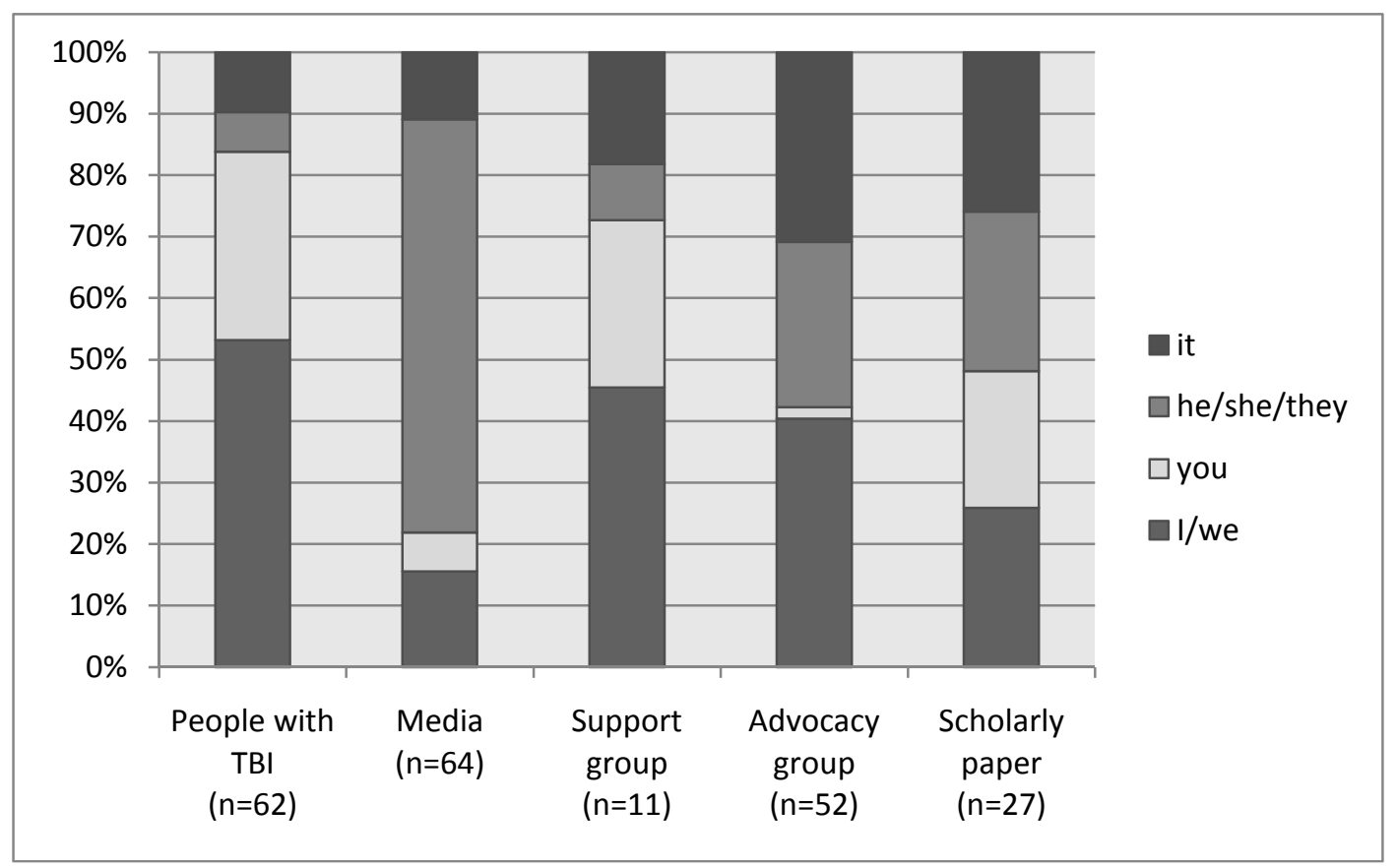

